\title{
Analysis of T-DNA alleles of flavonoid biosynthesis genes in Arabidopsis ecotype Columbia
}

\author{
Peter A Bowerman ${ }^{1,3}$, Melissa V Ramirez ${ }^{1,4}$, Michelle B Price ${ }^{1,5}$, Richard F Helm² and Brenda SJ Winkel ${ }^{* *}$
}

\begin{abstract}
Background: The flavonoid pathway is a long-standing and important tool for plant genetics, biochemistry, and molecular biology. Numerous flavonoid mutants have been identified in Arabidopsis over the past several decades in a variety of ecotypes. Here we present an analysis of Arabidopsis lines of ecotype Columbia carrying T-DNA insertions in genes encoding enzymes of the central flavonoid pathway. We also provide a comprehensive summary of various mutant alleles for these structural genes that have been described in the literature to date in a wide variety of ecotypes.

Findings: The confirmed knockout lines present easily-scorable phenotypes due to altered pigmentation of the seed coat (or testa). Knockouts for seven alleles for six flavonoid biosynthetic genes were confirmed by PCR and characterized by UPLC for altered flavonol content.

Conclusion: Seven mutant lines for six genes of the central flavonoid pathway were characterized in ecotype, Columbia. These lines represent a useful resource for integrating biochemical and physiological studies with genomic, transcriptomic, and proteomic data, much of which has been, and continues to be, generated in the Columbia background.
\end{abstract}

Keywords: Arabidopsis, Ecotype, Insertional inactivation lines, Flavonoid, Transparent testa

\section{Background}

Flavonoids are a group of specialized plant metabolites that play critical roles in plant reproduction, defense from abiotic and biotic stress and are of growing interest as health-promoting compounds in human and animal diets [1-3]. As pigments, they have also figured into numerous seminal biological discoveries including Mendel's elucidation of the laws of genetics, McClintock's discovery of mobile genetic elements, and more recently the phenomenon of cosuppression, or RNA interference, in Petunia hybrida (reviewed in $[4,5]$ ). The flavonoid pathway continues to serve as an important experimental system in a variety of plant species, with studies ranging from understanding complex transcriptional control to biochemical structure-function relationships, intra- and intercellular transport, and the subcellular organization

\footnotetext{
* Correspondence: winkel@vt.edu

'Department of Biological Sciences, Blacksburg, VA 24061, USA

Full list of author information is available at the end of the article
}

of pathways as multi-enzyme complexes [6-9]. Still, many questions remain about the specific biological targets of flavonoids in plants and animals $[1,10]$, while engineering the production of specific flavonoids in plants and microorganisms is still far from straight-forward $[11,12]$.

Mutations within genes in the flavonoid biosynthetic pathway of Arabidopsis were described as early as 1971, easily identified by the transparent testa $(t t)$ phenotype of the mutant seed coat [13] (Figure 1 and Table 1). Large-scale mutant screens carried out by Maarten Koornneef, initially aimed at characterizing the effects of fast-neutron and X-rays, identified many more flavonoid biosynthetic and regulatory genes $[14,15]$. Several other mutants were subsequently identified by Koornneef and others, almost all which have now been cloned and characterized [2]. While this represented an extremely useful toolset, these EMS and fast neutron induced mutations were isolated in a variety of ecotypes, primarily Landsberg but also several others, complicating the

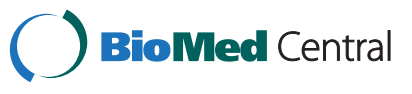




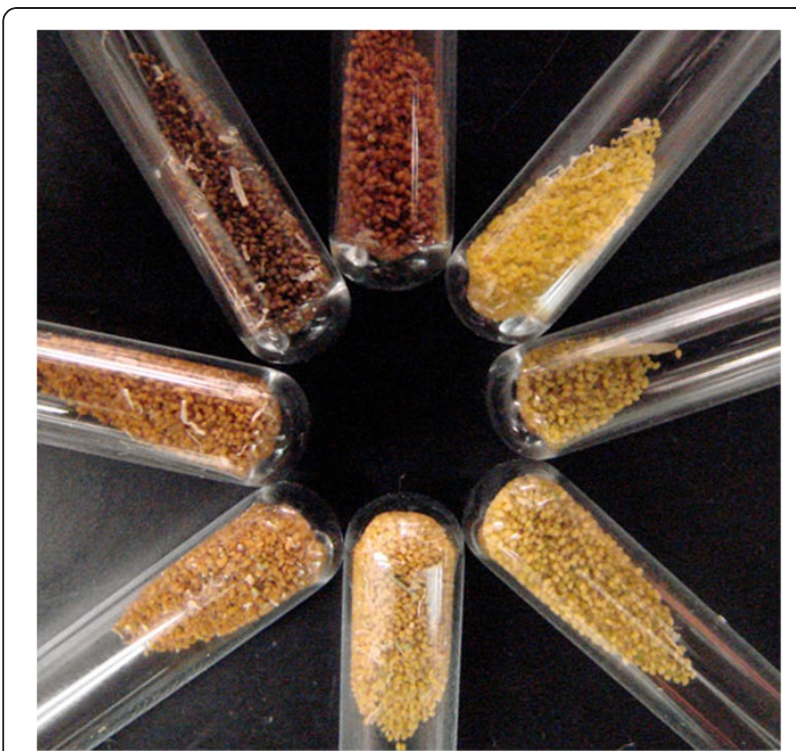

Figure 1 Seed coat color phenotype of confirmed homozygous T-DNA lines with insertions disrupting genes involved in flavonoid biosynthesis. From top center, clockwise seeds are: Col-0 WT, tt4-13, tt5-3, tt5-2, tt6-3, tt7-5, tt11-11, and ban-4.

analysis of differences between mutants. While differences between ecotypes are sometimes minimal, morphological differences between ecotypes can be easily identified by eye, and research indicates that there are important differences between these backgrounds [16-18]. Here we describe the confirmation and preliminary characterization of mutant alleles for genes encoding flavonoid enzymes in Arabidopsis ecotype Columbia-0 (Col-0) that are available as part of the SALK collection of T-DNA insertion lines [19]. These lines represent a useful set of tools for analyzing the organization of flavonoid biosynthetic enzymes and their end products, as well the cellular, physiological and ecological roles of flavonoids. We also present a compilation of mutant alleles for flavonoid structural gene that have been described in the literature to date in a variety of different ecotypes.

\section{Findings}

\section{Confirmation of homozygous $t t$ alleles}

T-DNA insertion lines in ecotype Col-0 were obtained from the Arabidopsis Biological Resource Center (ABRC, Columbus, $\mathrm{OH}$ ) for genes encoding six of the eight enzymes of the central flavonoid pathway: chalcone synthase (CHS, SALK_020583), chalcone isomerase (CHI, SALK_034145 and CS300857 from the GABI-Kat project), flavanone 3-hydroxylase (F3H, SALK_113904), flavonoid 3'-hydroxylase (F3'H, SALK_053394), anthocyanidin synthase (ANS, SALK_073183), and anthocyanidin reductase (ANR, SALK_040250). These lines were assigned allele numbers based on the previously- published alleles for each locus (Table 1). Note that a mutant allele for dihydroflavonol reductase (DFR) was recently identified in the Col-0 background that was not included in this study; no stable mutant allele has yet been identified in this ecotype for flavonol synthase 1 (FLS1).

DNA was isolated from leaves of each T-DNA line to screen for lines homozygous for each insertion. The ability to produce a PCR product from Col-0 wild-type plants using primers that span the T-DNA insertion site (Figure 2) was used to identify the presence of an intact gene. The absence of an amplicon using the same primers for T-DNA lines indicates that the insertion is present, while products generated using one T-DNA-specific and one gene-specific primer indicate the presence of a T-DNA insertion in the gene of interest. The results illustrated in Figure 3 identify each line as containing a homozygous T-DNA insertion in the gene of interest, most within the respective open reading frames, with the exception of alleles of CHI (SALK_034145) and FLSI (AJ588535), which contain insertions within the promoters, and CHI (CS300857) and ANR (SALK_040250) with insertion in introns. It should be noted that these lines may contain additional T-DNA insertions at other sites of the genome; it has not yet been determined whether that is the case for any of the lines described here.

\section{End product and pigmentation analyses of $t$ alleles}

Hydrolyzed flavonol extracts were analyzed by Ultra Performance Liquid Chromatography (UPLC) to provide phenotypic evidence of the gene disruptions identified by PCR. Five of the lines, $t t 4-13, t t 5-2, t t 5-3, t t 6-3$ and fls1-3, had no detectable levels of kaempferol or quercetin, the two major flavonol aglycones found in Arabidopsis (Figure 4). All five alleles affect enzymes upstream of flavonol production in the flavonoid biosynthetic pathway. As in previous analyses of the $t t 7-1$ allele in the Landsberg (Ler) background, which lacks the $\mathrm{F}^{\prime} \mathrm{H}$ enzyme, $t t 7-5$ in Col-0 also accumulated high levels of kaempferol but no detectable quercetin [46]. This is consistent with the catalytic role of $\mathrm{F3}^{\prime} \mathrm{H}$ in converting dihydrokaempferol to dihydroquercetin. The tt11-11 and ban-4 mutants contain insertions in the $A N S$ and $A N R$ genes, respectively. Both lines accumulated flavonols at levels comparable to wild type but displayed other phenotypes characteristic of defects in the respective genes. The $t t 11-11$ seeds exhibited an intermediate $t t$ phenotype (Figure 1), but adult plants were devoid of red pigmentation, consistent with an absence of anthocyanins, while ban-4 exhibited a red seed coat in immature seeds and a darker black seed coat in fully desiccated seeds, as described previously for ban-1 [41]. 
Table 1 Summary of enzyme-encoding tt alleles described to date

\begin{tabular}{|c|c|c|c|c|c|}
\hline Gene & Allele $^{1}$ & Line number ${ }^{2}$ & Ecotype $^{3}$ & Mutagen $^{4}$ & First described \\
\hline \multirow{14}{*}{$\begin{array}{l}\text { chalcone synthase } \\
\text { (CHS)at5g13930 }\end{array}$} & $t t 4-1$ & 85 & Ler & EMS & {$[14,20]$} \\
\hline & $t t 4-2$ & $2 Y Y 6$ & $\mathrm{Col}$ & EMS & {$[21-23]$} \\
\hline & $t t 4-3$ & $\mathrm{C} 1$ & $\mathrm{Col}$ & Carbon ions & {$[24]$} \\
\hline & $t t 4-4$ & $\mathrm{C} 2$ & $\mathrm{Col}$ & Carbon ions & \\
\hline & $t t 4-5$ & UV01 & Ler & y radiation & {$[25]$} \\
\hline & $t+4-6$ & UV25 & Ler & EMS & \\
\hline & $t t 4-7$ & UV113 & Ler & r radiation & \\
\hline & $t t 4-8$ & UV118a & Ler & y radiation & \\
\hline & $t t 4-9$ & $38 \mathrm{G} 1 \mathrm{R}$ & Ler & r radiation & \\
\hline & $t t 4-10$ & & Est-1 & EMS & {$[26]$} \\
\hline & $t t 4-11$ & DFW34 & Ws-2 & T-DNA & {$[27]$} \\
\hline & $t t 4-12$ & CS429127 / GK-304D03 & $\mathrm{Col}$ & T-DNA & {$[28]$} \\
\hline & $t t 4-13$ & SALK_020583 ${ }^{5}$ & Col-0 & T-DNA & {$[29,30]$} \\
\hline & tt4-14 through 21 & & & zinc finger nucleases & {$[31]$} \\
\hline \multirow{3}{*}{$\begin{array}{l}\text { chalcone isomerase } \\
(\mathrm{CHI}) \text { at3g55120 }\end{array}$} & $t+5-1$ & 86 & & EMS & {$[14]$} \\
\hline & $t+5-2$ & CS300857/ GK-176H03 & Col & T-DNA & {$[28,30]$; this report } \\
\hline & $t t 5-3$ & SALK_034145 & Col-0 & T-DNA & This report \\
\hline \multirow{8}{*}{$\begin{array}{l}\text { flavanone 3-hydroxylase } \\
\text { (F3H)at3g51240 }\end{array}$} & $t+6-1$ & 87 & Ler & EMS & {$[14,32]$} \\
\hline & f3h-2::En & & $\mathrm{Col}$ & Transposon & {$[32]$} \\
\hline & f3h-3::En & & $\mathrm{Col}$ & Transposon & \\
\hline & $f 3 h-4 f$ & & $\mathrm{Col}$ & Transposon & \\
\hline & $f 3 h-5 f$ & & $\mathrm{Col}$ & Transposon & \\
\hline & $t t 6-2$ & CS427992 / GK-292E08 & Col-0 & T-DNA & {$[28]$} \\
\hline & $t t 6-3$ & SALK_113904 5 & Col-0 & T-DNA & {$[33]$} \\
\hline & $t+6-4$ & SALK_023664 & Col-0 & T-DNA & $\begin{array}{l}\text { Leaky allele - } \\
\text { unpublished results }\end{array}$ \\
\hline \multirow{5}{*}{$\begin{array}{l}\text { flavonoid 3'-hydroxylase } \\
\text { (F3'H)at5g07990 }\end{array}$} & $t t 7-1$ & 88 & Ler & EMS & {$[14,34]$} \\
\hline & $t t 7-2$ & & Col-7 & T-DNA & {$[35]$} \\
\hline & $t t 7-3$ & CS433473 / GK-349F05 & Col-0 & T-DNA & {$[28,30]$} \\
\hline & $t t 7-4$ & DJ111 & Ws-2 & T-DNA & {$[27]$} \\
\hline & $t t 7-5$ & SALK_053394 & Col-0 & T-DNA & {$[36]$} \\
\hline \multirow{5}{*}{$\begin{array}{l}\text { dihydroflavonol } \\
\text { 4-reductase } \\
\text { (DFR) at5g42800 }\end{array}$} & $t+3-1$ & 84 & Ler & EMS & {$[37]$} \\
\hline & $t+3-2$ & CS428258 / GK-295C10 & Col-0 & T-DNA & {$[28]$} \\
\hline & $t+3-3$ & & Est-1 & fast neutrons & {$[26]$} \\
\hline & & GK-212G01 & Col-0 & T-DNA & $\begin{array}{l}\text { Some segregants } \\
\text { have pale brown } \\
\text { seeds, none yellow }\end{array}$ \\
\hline & & SALK_099848 & Col-0 & T-DNA & Does not have phenotype \\
\hline \multirow[t]{6}{*}{$\begin{array}{l}\text { anthocyanidin synthase } \\
\text { (ANS/LDOX)at4g22880 }\end{array}$} & $t t 11-1$ & & & & $\begin{array}{l}\text { Debeaujon and Koornneef, } \\
\text { unpublished }\end{array}$ \\
\hline & $t t 11-2$ & & Ler & EMS & {$[38]$} \\
\hline & $t d s 4-1$ & & Ws-4 & $\begin{array}{l}\text { T-DNA but not } \\
\text { tagged (INRA) }\end{array}$ & {$[35]$} \\
\hline & $t d s 4-2$ & SALK_028793 & Col-0 & T-DNA & {$[39]$} \\
\hline & $t d s 4-3$ & CSHL GT9767 & Ler & Gene trap & \\
\hline & $t+17$ & & Est-1 & Fast neutrons & {$[26]$} \\
\hline
\end{tabular}


Table 1 Summary of enzyme-encoding tt alleles described to date (Continued)

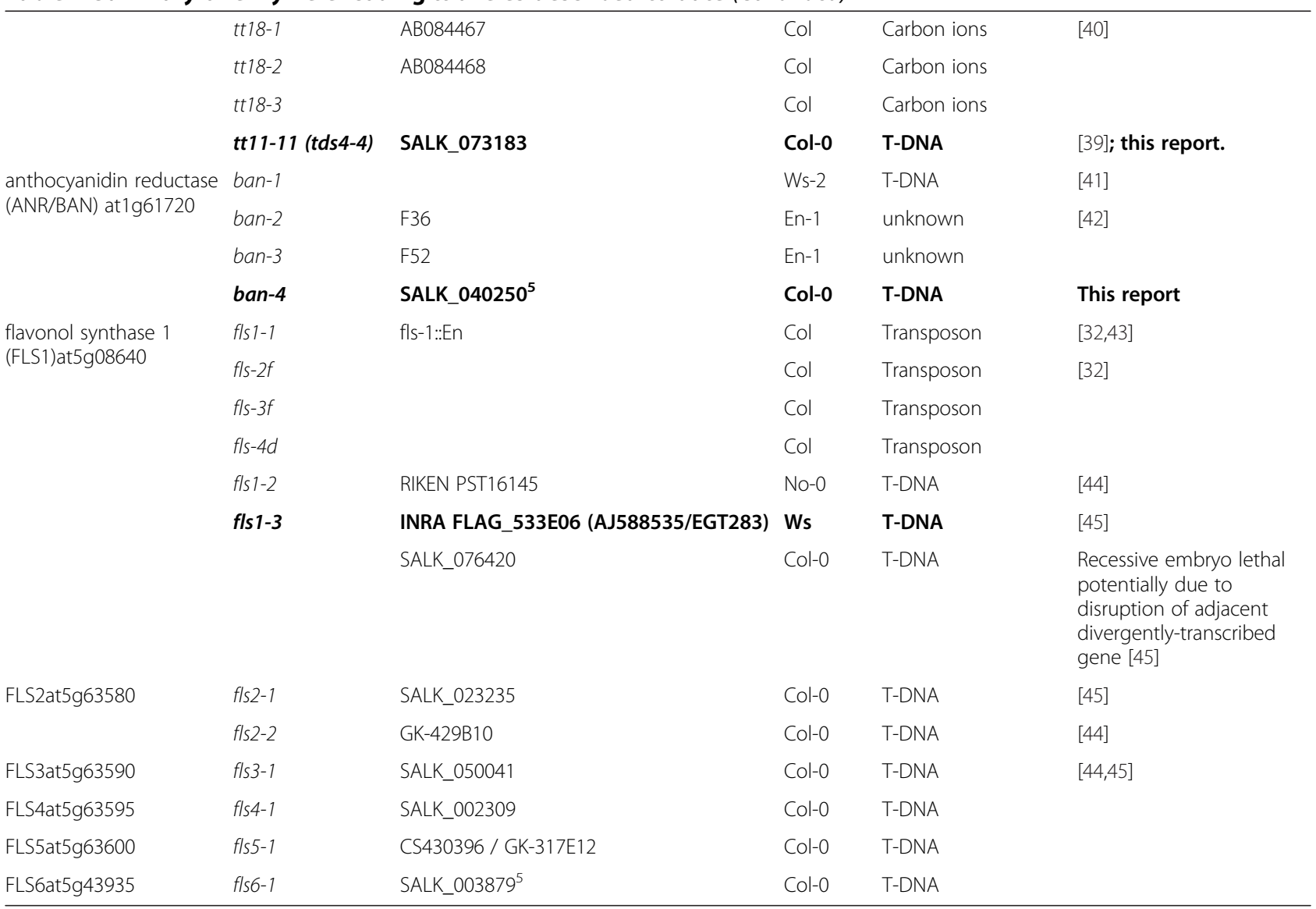

${ }^{1}$ Alleles in bold are described in the current study.

${ }^{2} \mathrm{GK}=\mathrm{GABI}-$ Kat.

${ }^{3}$ Standard ecotype abbreviations, as follows: Landsberg erecta (Ler); Columbia accession number 0 (Col-0) or accession unknown (Col), ; Enkheim (En-1); Estland (Est-1); Wassilewskija (Ws-2).

${ }^{4}$ ethyl methanesulfonate (EMS).

${ }^{5}$ independently-derived homozygote already available at ABRC.

\section{Conclusions}

The flavonoid mutants described in this report represent a useful toolset for the study of many aspects of plant metabolism, cell biology, and physiology. The flavonoid pathway provides a unique model system for studying metabolic pathways as it has been well-characterized in a variety of model organisms and is essential for a wide range of cellular and physiological processes. Mutations for genes encoding many of the enzymes now exist in a uniform genetic background. While this communication focuses on flavonoid biosynthetic enzymes, mutant alleles exist for genes involved in mediating other aspects of flavonoid metabolism, including transcriptional regulation of gene expression and modification and cellular transport of pathway end products [47,48].

The flavonoid enzymes disrupted by T-DNA insertions have been hypothesized to participate in metabolic channeling via protein-protein interactions $[7,49]$. These mutations, all within the same genetic background, could greatly enhance our understanding of the regulation and dynamics of this channeling, which has broad reaching implications across metabolic research areas. The CHS mutant allele, $t t 4-13$, has already been used by our group and others to further probe the involvement of this pathway in modulating the distribution of auxin and ethylene within Arabidopsis seedling roots [7,29,36,50], to characterize the distribution of flux among branch pathways of flavonoid metabolism [45], and to identify molecules that promote pollen fertilization in Arabidopsis [51]. The CHI allele, $t t 5-3$, has been used in a metabolic profiling analysis of the response to UV light [52], whereas $t t 5-2$ was used to demonstrate a requirement for this $\mathrm{CHI}$ gene, among flavonoid genes, for flavonol synthesis in pollen [30]. The flavanone 3-hydroxylase mutant, $t t 6-3$, has been used to characterize the biochemical activities of Arabidopsis F3H and Sorghum FNS [33,53], while the flavonoid 3 -hydroxylase line, $t t 7-5$, was used by our group in the auxin-ethylene study [36], and $t t 11-11$, was already used several years ago to show that TDS4 is allelic to $t t 18$ (now renamed $t t 11$ per the findings of [38]) and encodes 


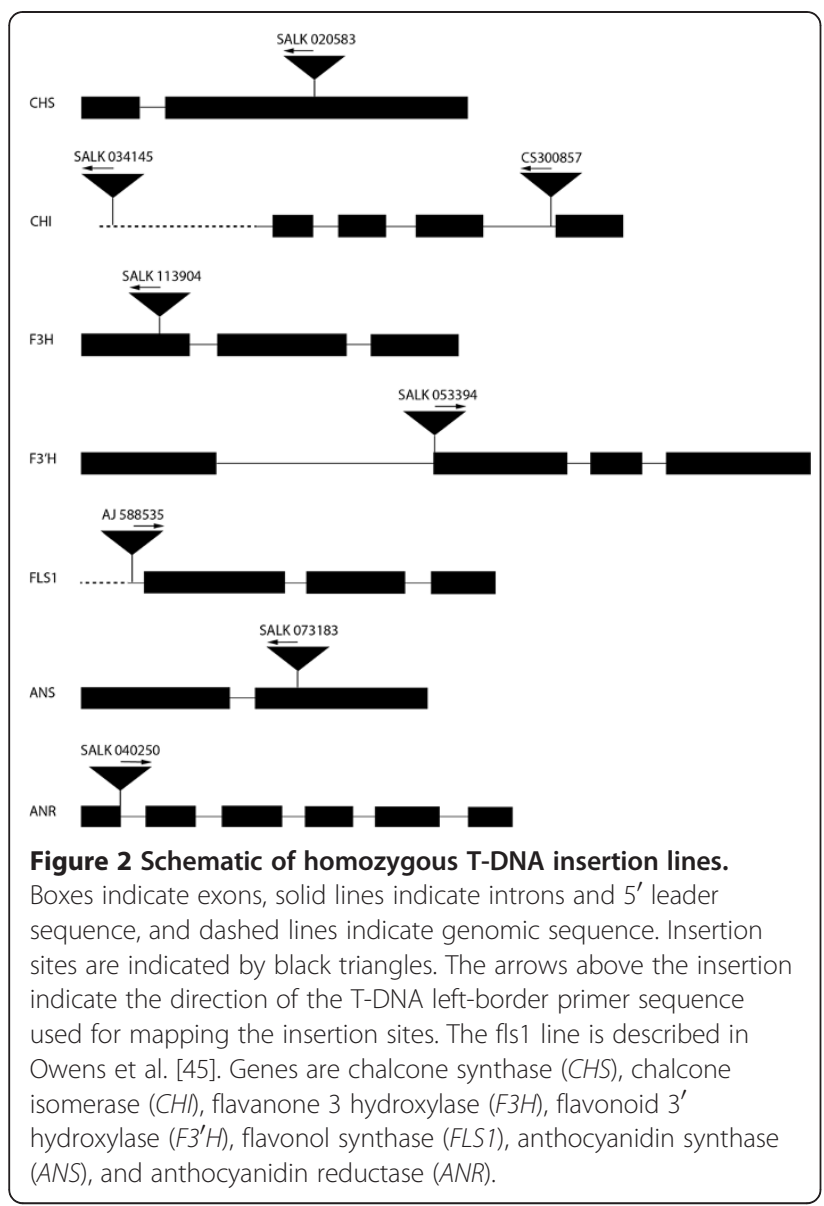

LDOX/ANS. The F3H and LDOX lines, $t t 6-3$ and $t t 11-11$, have been used to demonstrate the utility of a novel metabolic profiling method for intact seed [54].

The collection of $t t$ mutants presented here represent a means to several ends. As our understanding of the roles flavonoid compounds play in human health evolve, so too may our need to develop new crop lines to deliver increased amounts of these compounds in our diet. In addition, the flavonoid pigmentation compounds are of great horticultural importance. For these two reasons alone a thorough understanding of the dynamic metabolic processes involved in flavonoid production is important, but there are broader benefits to many areas of cellular and plant biology.

\section{Methods}

\section{Analysis of flavonol profiles}

Arabidopsis (Columbia ecotype) wild-type and transgenic seeds were surface-sterilized as described previously [25]. Approximately $5 \mathrm{mg}$ of seeds were dispersed on agar plates containing Murashige and Skoog salts with $1 \%$ sucrose and incubated $2 \mathrm{~d}$ in the dark at $4^{\circ} \mathrm{C}$. The seeds were then grown on the surface of the agar medium under continuous white light $\left(100 \mu \mathrm{E} \mathrm{m}^{-2} \mathrm{~s}^{-1}\right)$ at $21^{\circ} \mathrm{C}$ as previously described [55]. Flavonols were extracted from

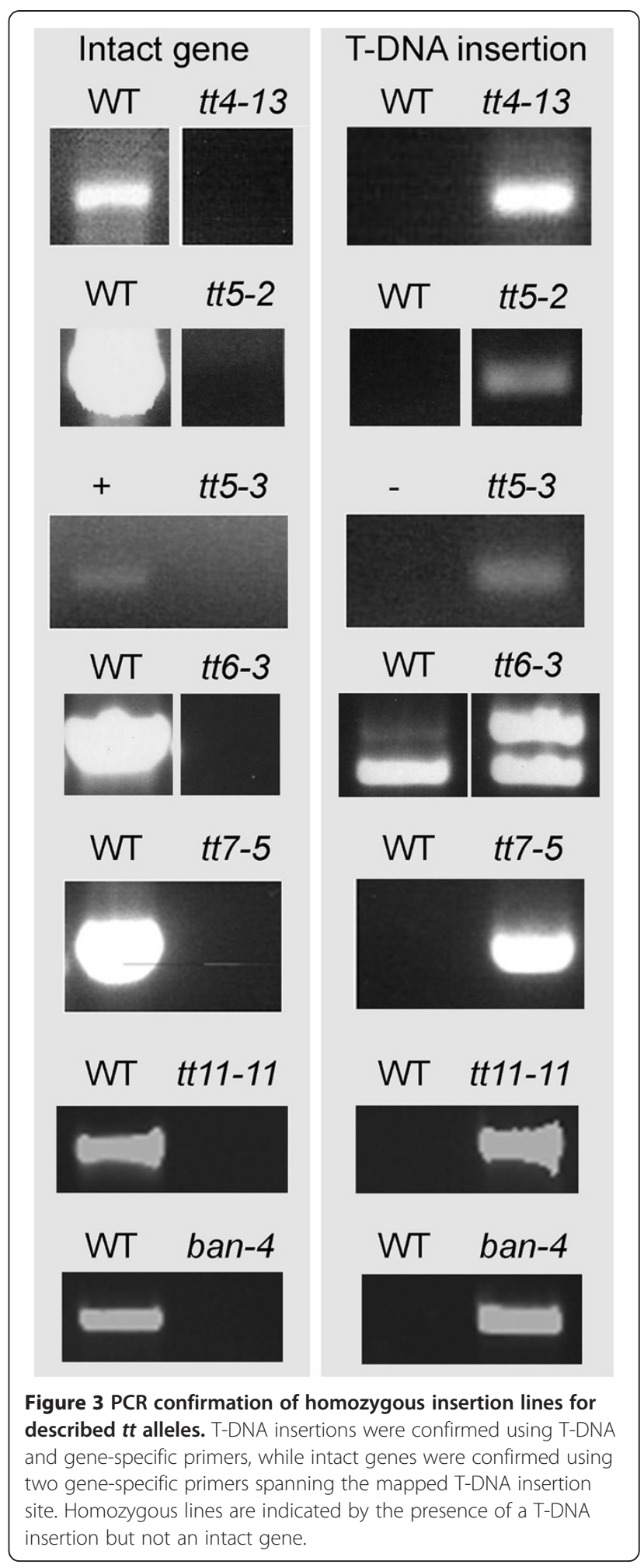

frozen tissue by grinding 20 seedlings in $200 \mu \mathrm{l} 1 \%$ acetic acid in $80 \%$ methanol and incubating overnight at $4{ }^{\circ} \mathrm{C}$. The samples were clarified by centrifugation twice at $13,000 \mathrm{rpm}, 4^{\circ} \mathrm{C}$ for $15 \mathrm{~min}$ each time. The samples were 

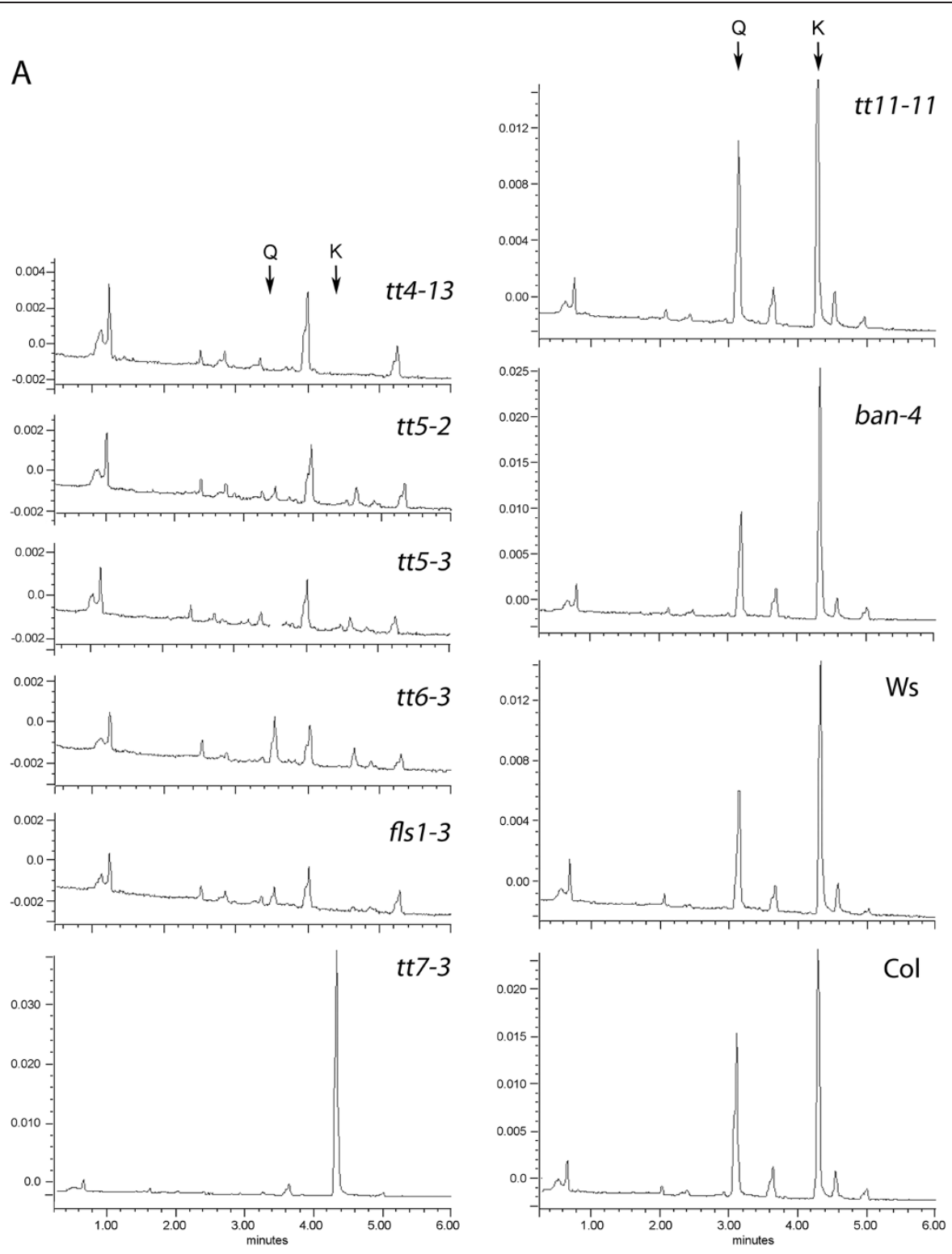

B

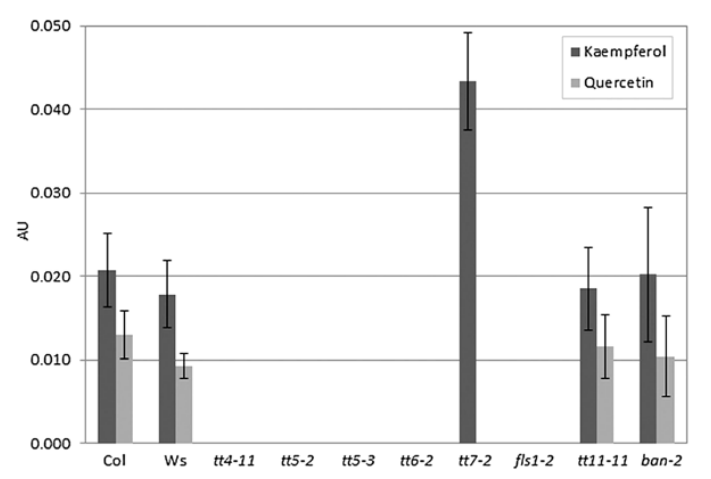

Figure 4 (See legend on next page.) 
(See figure on previous page.)

Figure 4 UPLC analysis of flavonol aglycone profiles in T-DNA insertion lines. A) UPLC traces of hydrolyzed extracts prepared from 5-day-old seedlings, with arrows indicating the retention times of the flavonols, quercetin (Q) and kaempferol (K). B) Comparison of kaempferol and quercetin levels determined from integrated peak areas.

hydrolyzed as described in Burbulis et al. [21], followed by the addition of an equal volume of $100 \%$ methanol and centrifugation as before.

Flavonols in wild-type and transgenic seedlings were profiled using a Waters Acquity UPLC system with a UPLC phenyl C18 column (2.1 mm x $100 \mathrm{~mm}$, Waters) and a linear elution gradient from $100 \%$ solvent A $(0.1 \%$ formic acid in water) to $40 \%$ solvent B $(0.1 \%$ formic acid in acetonitrile) over $13 \mathrm{~min}$ at $4^{\circ} \mathrm{C}$, modified from Yonekura-Sakakibara [56]. Chromatograms were collected at $320 \mathrm{~nm}$ and $365 \mathrm{~nm}$.

\section{Confirmation of knockouts by T-DNA insertion}

Lines for each $t t$ allele in Col- 0 were ordered from the Arabidopsis Biological Resource Center (ABRC; The Ohio
State University) and bred to homozygosity from a segregating population. The mapped locations of each T-DNA insertion were created using the T-DNA flanking sequence identified via the ABRC sequence viewer (Figure 2). To confirm that each line was homozygous, genomic DNA was extracted from one large leaf from each plant according to Edwards et al. [57] with slight modifications. Genomic DNA from Col-0 wild-type plants of approximately the same age was also extracted in the same manner to serve as a control template. Extracted genomic DNA was resuspended overnight in $100 \mu \mathrm{ldd} \mathrm{d}_{2} \mathrm{O}$. PCR was performed using 1 to $2 \mu \mathrm{l}$ of each sample with the primers listed in Table 2 in a total volume of $10-20 \mu \mathrm{l}$. PCR products were analyzed by agarose gel electrophoresis. Seeds for the $t t 5-3, t t 7-5$, and $t t 11-11$ homozygous lines have been

Table 2 Primers used for confirmation of homozygous lines

\begin{tabular}{|c|c|c|}
\hline Allele & Primer sequence $\left(5^{\prime}-3^{\prime}\right)$ & \\
\hline CHS: $t t 4-13$ & Intact Gene & GATCACTCATGTCGTCTTCTG \\
\hline \multirow[t]{3}{*}{ (SALK_020583) } & & AGGGCCAGGCGGTGAAG \\
\hline & T-DNA insertion & GATCACTCATGTCGTCTTCTG \\
\hline & & TTAGAGAGGAACGCTGTGC \\
\hline $\mathrm{CHI}: t t 5-2$ & Intact Gene & ATGTCTTCATCCAACGCCTG \\
\hline \multirow[t]{2}{*}{ (CS300857) } & & GTTCTCTITGGCTAGTTITC \\
\hline & T-DNA insertion & ATGTCTTCATCCAACGCCTG \\
\hline $\mathrm{CHI}: t t 5-3$ & Intact Gene & CGAAAGTAAGAATTAGAGAATAC \\
\hline \multirow[t]{2}{*}{ (SALK_034145) } & & AGGGCCAGGCGGTGAAG \\
\hline & T-DNA insertion & CGAAAGTAAGAATTAGAGAATAC TGATAAACTTCTCAAACGCAC \\
\hline $\mathrm{F} 3 \mathrm{H}: \mathrm{tt} 6-3$ & Intact Gene & TGGTAGGTAGCTAGCGAC \\
\hline \multirow[t]{3}{*}{ (SALK_113904) } & & AACACACCGCGCCTAGC \\
\hline & T-DNA insertion & TGGTAGGTAGCTAGCGAC \\
\hline & & AGGGCCAGGCGGTGAAG \\
\hline$F 3^{\prime} H: t t 7-5$ & Intact Gene & CAGCGGATTGGAATTTGAAC \\
\hline \multirow[t]{3}{*}{ (SALK_053394) } & & CAGCTGTGAACATGTTCTG \\
\hline & T-DNA insertion & GGACCGCTTGCTGCAACT \\
\hline & & CAGCTGTGAACATGTTCTG \\
\hline ANS: $t t 11-11$ & Intact Gene & AGAGTTGAGAGTCTAGC \\
\hline \multirow[t]{3}{*}{ (SALK_073183) } & & GCAAAAGTCCGTGGAG \\
\hline & T-DNA insertion & AGAGTTGAGAGTCTAGC \\
\hline & & TGGTTCACGTAGTGGGCCATCG \\
\hline ANR: ban-4 & Intact Gene & TGGACCAGACTCTTAC \\
\hline \multirow[t]{3}{*}{ (SALK_040250) } & & AGACCGGTCACATGC \\
\hline & T-DNA insertion & AGACCGGTCACATGC \\
\hline & & TGGTTCACGTAGTGGGCCATCG \\
\hline
\end{tabular}


deposited with the ABRC; homozygous lines are available at the ABRC for the other four lines through the SALK Confirmed T-DNA Project.

\section{Abbreviations}

ANR: anthocyanidin reductase; ANS: anthocyanidin synthase; BAN: Banyuls; $\mathrm{CH}$ : chalcone isomerase; $\mathrm{CHS}$ : chalcone synthase; $\mathrm{F}^{\prime} \mathrm{H}$ : flavonoid $3^{\prime}$ hydroxylase; FLS: flavonol synthase; F3H: flavanone 3-hydroxylase; tt: transparent testa; UPLC: Ultra performance liquid chromatography.

\section{Competing interests}

The authors declare that they have no competing interests.

\section{Authors' contributions}

PAB characterized several of the T-DNA insertions by PCR, produced the photograph showing the differences in seed coat color, and drafted the manuscript. MVR characterized several additional T-DNA insertions by PCR and participated in editing the manuscript. MM and RFH contributed the UPLC analysis. BSJW designed the study and participated in drafting and editing the manuscript. All authors read and approved the final manuscript.

\section{Acknowledgments}

The authors thank the Arabidopsis Biological Resource Center for providing seeds for T-DNA lines characterized in this report. We also acknowledge Brad Howard's contribution to the analysis of the $t t 6-3$ line. The work was supported by grants from the NSF Molecular Biochemistry (MCB-0445878) and IGERT (DGE-0523658) programs. Additional support for PB and MM was provided by the Molecular Plant Sciences Graduate Program at Virginia Tech.

\section{Author details}

'Department of Biological Sciences, Blacksburg, VA 24061, USA. ${ }^{2}$ Department of Biochemistry, Virginia Tech, Blacksburg, VA 24061, USA. ${ }^{3}$ Current address: Department of Biology, Colorado State University, Fort Collins, CO 80523, USA. ${ }^{4}$ Current address: Department of Microbiology, Immunology \& Pathology, Colorado State University, Fort Collins, CO 80523, USA. ${ }^{5}$ Current address: Department of Plant Pathology, Physiology, and Weed Science, Virginia Tech, Blacksburg, VA 24061, USA.

\section{Received: 27 April 2012 Accepted: 23 August 2012}

Published: 4 September 2012

\section{References}

1. Buer CS, Imin N, Djordjevic MA: Flavonoids: New roles for old molecules. J Integr Plant Biol 2010, 52(1):98-111.

2. Lepiniec L, Debeaujon I, Routaboul JM, Baudry A, Pourcel L, Nesi N, Caboche M: Genetics and biochemistry of seed flavonoids. Annu Rev Plant Biol 2006, 57:405-430.

3. Prochazkova D, Bousova I, Wilhelmova N: Antioxidant and prooxidant properties of flavonoids. Fitoterapia 2011, 82(4):513-523.

4. Koes R, Verweij W, Quattrocchio F: Flavonoids: a colorful model for the regulation and evolution of biochemical pathways. Trends Plant Sci 2005, 10(5):236-242.

5. Winkel BSJ: The biosynthesis of flavonoids. In The Science of Flavonoids. Edited by Grotewold E. New York: Springer Science \& Business Media; 2006:71-95.

6. Austin MB, O'Maille PE, Noel JP: Evolving biosynthetic tangos negotiate mechanistic landscapes. Nat Chem Biol 2008, 4(4):217-222

7. Crosby KC, Pietraszewska-Bogiel A, Gadella TWJ, Winkel BSJ: Forster resonance energy transfer demonstrates a flavonoid metabolon in living plant cells that displays competitive interactions between enzymes. FEBS Lett 2011, 585(14):2193-2198.

8. Feller A, Machemer K, Braun EL, Grotewold E: Evolutionary and comparative analysis of MYB and bHLH plant transcription factors. Plant J 2011, 66(1):94-116.

9. Zhao J, Dixon RA: The 'ins' and 'outs' of flavonoid transport. Trends Plant Sci 2010, 15(2):72-80

10. Hernandez I, Alegre L, Van Breusegem F, Munne-Bosch S: How relevant are flavonoids as antioxidants in plants? Trends Plant Sci 2009, 14(3):125-132.

11. Santos CNS, Koffas M, Stephanopoulos G: Optimization of a heterologous pathway for the production of flavonoids from glucose. Metab Eng 2011, 13(4):392-400
12. Tanaka Y, Brugliera F, Kalc G, Senior M, Dyson B, Nakamura N, Katsumoto $Y$, Chandler S: Flower color modification by engineering of the flavonoid biosynthetic pathway: Practical perspectives. Biosci Biotechnol Biochem 2010, 74(9):1760-1769.

13. Bürger D: Die morphologischen Mutanten des Göttinger ArabidopsisSortiment, einschliesslich der Mutanten mit abweichender Samenfarbe. Arabid Inf Serv 1971, 8:36-42.

14. Koornneef M: Mutations affecting the testa color in Arabidopsis. Arabid Inf Serv 1990, 28:1-4.

15. Koornneef M, Dellaert LW, van der Veen JH: EMS- and radiation-induced mutation frequencies at individual loci in Arabidopsis thaliana (L.) Heynh. Mutat Res 1982, 93(1):109-123.

16. Beemster GTS, De Vusser K, De Tavernier E, De Bock K, Inze D: Variation in growth rate between Arabidopsis ecotypes is correlated with cell division and A-type cyclin-dependent kinase activity. Plant Physiol 2002, 129(2):854-864.

17. Chevalier F, Martin O, Rofidal V, Devauchelle AD, Barteau S, Sommerer N, Rossignol M: Proteomic investigation of natural variation between Arabidopsis ecotypes. Proteomics 2004, 4(5):1372-1381.

18. Maloof JN, Borevitz JO, Dabi T, Lutes J, Nehring RB, Redfern JL, Trainer GT, Wilson JM, Asami T, Berry CC, et al: Natural variation in light sensitivity of Arabidopsis. Nat Genet 2001, 29(4):441-446.

19. Alonso J, Stepanova A, Leisse T, Kim C, Chen H, Shinn P, Stevenson D, Zimmerman J, Barajas P, Cheuk R, et al: Genome-wide insertional mutagenesis of Arabidopsis thaliana. Science 2003, 301:653-657.

20. Feinbaum RL, Ausubel FM: Transcriptional regulation of the Arabidopsis thaliana chalcone synthase gene. Mol Cell Biol 1988, 8(5):1985-1992.

21. Burbulis IE, lacobucci M, Shirley BW: A null mutation in the first enzyme of flavonoid biosynthesis does not affect male fertility in Arabidopsis. Plant Cell 1996, 8(6):1013-1025.

22. Brown DE, Rashotte AM, Murphy AS, Normanly J, Tague BW, Peer WA, Taiz L, Muday GK: Flavonoids act as negative regulators of auxin transport in vivo in Arabidopsis thaliana. Plant Physiol 2001, 126:524-535.

23. Bennett T, Sieberer T, Willett B, Booker J, Luschnig C, Leyser O: The Arabidopsis MAX pathway controls shoot branching by regulating auxin transport. Current Biology 2006, 16(6):553-563.

24. Shikazono N, Yokota Y, Tanaka A, Watanabe H, Tano S: Molecular analysis of carbon ion-induced mutations in Arabidopsis thaliana. Genes Genet Syst 1998, 73(3):173-179.

25. Saslowsky DE, Dana CD, Winkel-Shirley B: An allelic series for the chalcone synthase locus in Arabidopsis. Gene 2000, 255(2):127-138.

26. Bharti AK, Khurana JP: Molecular characterization of transparent testa (tt) mutants of Arabidopsis thaliana (ecotype Estland) impaired in flavonoid biosynthetic pathway. Plant Sci 2003, 165(6):1321-1332.

27. Routaboul JM, Kerhoas L, Debeaujon I, Pourcel L, Caboche M, Einhorn J, Lepiniec $L$ : Flavonoid diversity and biosynthesis in seed of Arabidopsis thaliana. Planta 2006, 224:96-107.

28. Rosso MG, Li Y, Strizhov N, Reiss B, Dekker K, Weisshaar B: An Arabidopsis thaliana T-DNA mutagenized population (GABI-Kat) for flanking sequence tag-based reverse genetics. Plant Mol Biol 2003, 53(1-2):247-259.

29. Buer CS, Sukumar P, Muday GK: Ethylene modulates flavonoid accumulation and gravitropic responses in roots of Arabidopsis. Plant Physiology 2006, 140(4):1384-1396.

30. Stracke R, Jahns O, Keck M, Tohge T, Niehaus K, Fernie AR, Weisshaar B: Analysis of PRODUCTION OF FLAVONOL GLYCOSIDES-dependent flavonol glycoside accumulation in Arabidopsis thaliana plants reveals MYB11-, MYB12-and MYB111-independent flavonol glycoside accumulation. New Phytol 2010, 188(4):985-1000.

31. Zhang F, Maeder ML, Unger-Wallace E, Hoshaw JP, Reyon D, Christian M, Li XH, Pierick CJ, Dobbs D, Peterson T, et al: High frequency targeted mutagenesis in Arabidopsis thaliana using zinc finger nucleases. $P$ Nat Acad Sci USA 2010, 107(26):12028-12033.

32. Wisman E, Hartmann U, Sagasser M, Baumann E, Palme K, Hahlbrock K Saedler H, Weisshaar B: Knock-out mutants from an En-1 mutagenized Arabidopsis thaliana population generate phenylpropanoid biosynthesis phenotypes. Proc Natl Acad Sci USA 1998, 95:12432-12437.

33. Owens DK, Crosby KC, Runac J, Howard BA, Winkel BSJ: Biochemical and genetic characterization of Arabidopsis flavanone 3 beta-hydroxylase. Plant Physiology and Biochemistry 2008, 46(10):833-843. 
34. Schoenbohm C, Martens S, Eder C, Forkmann G, Weisshaar B: Identification of the Arabidopsis thaliana flavonoid 3'-hydroxylase gene and functional expression of the encoded P450 enzyme. Biol Chem 2000, 381(8):749-753.

35. Abrahams S, Tanner GJ, Larkin PJ, Ashton AR: Identification and biochemical characterization of mutants in the proanthocyanidin pathway in Arabidopsis. Plant Physiol 2002, 130(2):561-576.

36. Lewis DR, Ramirez MV, Miller ND, Vallabhaneni P, Ray WK, Helm RF, Winkel BSJ, Muday GK: Auxin and ethylene induce flavonol accumulation through distinct transcriptional networks. Plant Physiology 2011, 156(1):144-164.

37. Shirley B, Hanley S, Goodman H: Effects of ionizing radiation on a plant genome: analysis of two Arabidopsis transparent testa mutations. Plant Cell 1992, 4(3):333.

38. Appelhagen I, Jahns O, Bartelniewoehner L, Sagasser M, Weisshaar B, Stracke R: Leucoanthocyanidin dioxygenase in Arabidopsis thaliana: characterization of mutant alleles and regulation by MYB-BHLH-TTG1 transcription factor complexes. Gene 2011, 484(1-2):62-69.

39. Abrahams S, Lee E, Walker AR, Tanner GJ, Larkin PJ, Ashton AR: The Arabidopsis TDS4 gene encodes leucoanthocyanidin dioxygenase (LDOX) and is essential for proanthocyanidin synthesis and vacuole development. Plant J 2003, 35(5):624-636

40. Shikazono N, Yokota Y, Kitamura S, Suzuki C, Watanabe H, Tano S, Tanaka A: Mutation rate and novel $t t$ mutants of Arabidopsis thaliana induced by carbon. Genetics 2003, 163(4):1449-1455.

41. Albert S, Delseny M, Devic M: BANYULS, a novel negative regulator of flavonoid biosynthesis in the Arabidopsis seed coat. Plant J 1997, 11(2):289-299.

42. Devic M, Guilleminot J, Debeaujon I, Bechtold N, Bensaude E, Koornneef M, Pelletier G, Delseny M: The BANYULS gene encodes a DFR-like protein and is a marker of early seed coat development. Plant J 1999, 19(4):387-398.

43. Preuss A, Stracke R, Weisshaar B, Hillebrecht A, Matern U, Martens S: Arabidopsis thaliana expresses a second functional flavonol synthase. FEBS Lett 2009, 583(12):1981-1986.

44. Stracke R, De Vos RCH, Bartelniewoehner L, Ishihara H, Sagasser M, Martens S, Weisshaar B: Metabolomic and genetic analyses of flavonol synthesis in Arabidopsis thaliana support the in vivo involvement of leucoanthocyanidin dioxygenase. Planta 2009, 229:427-445.

45. Owens DK, Alerding AB, Crosby KC, Bandara AB, Westwood JH, Winkel BSJ: Functional analysis of a predicted flavonol synthase gene family in Arabidopsis. Plant Physiol 2008, 147(3):1046-1061.

46. Pelletier M, Burbulis I, Winkel-Shirley B: Disruption of specific flavonoid genes enhances the accumulation of flavonoid enzymes and end-products in Arabidopsis seedlings. Plant Mol Biol 1999, 40(1):45-54.

47. Debeaujon I, Peeters AJ, Leon-Kloosterziel KM, Koornneef M: The transparent testa12 gene of Arabidopsis encodes a multidrug secondary transporter-like protein required for flavonoid sequestration in vacuoles of the seed coat endothelium. Plant Cell 2001, 13(4):853-871.

48. Nesi N, Debeaujon I, Jond C, Pelletier G, Caboche M, Lepiniec L: The TT8 gene encodes a basic helix-loop-helix domain protein required for expression of DFR and BAN genes in Arabidopsis siliques. Plant Cell 2000, 12(10):1863-1878.

49. Burbulis I, Winkel-Shirley B: Interactions among enzymes of the Arabidopsis flavonoid biosynthetic pathway. Proc Natl Acad Sci U S A 1999, 96(22):12929.

50. Vanholme R, Ralph J, Akiyama T, Lu F, Pazo JR, Kim H, Christensen JH, Van Reusel B, Storme $V$, De Rycke R, et al: Engineering traditional monolignols out of lignin by concomitant up-regulation of $\mathrm{F} 5 \mathrm{H} 1$ and downregulation of COMT in Arabidopsis. Plant J 2010, 64(6):885-897.

51. Qin Y, Wysocki RJ, Somogyi A, Feinstein Y, Franco J, Tsukamoto T, Dunatunga D, Clara L, Smith D, Simpson R, et al: Sulfinylated azadecalins act as functional mimics of a pollen germination stimulant in Arabidopsis pistils. Plant J 2011, 68(5):800-815.

52. Kusano M, Tohge T, Fukushima A, Kobayashi M, Hayashi N, Otsuki H, Kondou Y, Goto H, Kawashima M, Matsuda F, et al: Metabolomics reveals comprehensive reprogramming involving two independent metabolic responses of Arabidopsis to UV-B light. Plant J 2011, 67(2):354-369.

53. Du YG, Chu H, Wang MF, Chu IK, Lo C: Identification of flavone phytoalexins and a pathogen-inducible flavone synthase II gene (SbFNSII) in sorghum. Journal of Experimental Botany 2010, 61(4):983-994.

54. Kim SW, Kim HJ, Kim JH, Kwon YK, Ahn MS, Jang YP, Liu JR: A rapid, simple method for the genetic discrimination of intact Arabidopsis thaliana mutant seeds using metabolic profiling by direct analysis in real-time mass spectrometry. Plant Methods 2011, 7:14.

55. Saslowsky D, Winkel-Shirley B: Localization of flavonoid enzymes in Arabidopsis roots. Plant J 2001, 27:37-48.

56. Yonekura-Sakakibara K, Tohge T, Matsuda F, Nakabayashi R, Takayama H, Niida R, Watanabe-Takahashi A, Inoue E, Saito K: Comprehensive flavonol profiling and transcriptome coexpression analysis leading to decoding gene-metabolite correlations in Arabidopsis. Plant Cell 2008,

20(8):2160-2176

57. Edwards K, Johnstone C, Thompson C: A simple and rapid method for the preparation of plant genomic DNA for PCR analysis. Nucleic Acids Res 1991, 19(6):1349.

doi:10.1186/1756-0500-5-485

Cite this article as: Bowerman et al: Analysis of T-DNA alleles of flavonoid biosynthesis genes in Arabidopsis ecotype Columbia. BMC Research Notes 2012 5:485.

\section{Submit your next manuscript to BioMed Central and take full advantage of:}

- Convenient online submission

- Thorough peer review

- No space constraints or color figure charges

- Immediate publication on acceptance

- Inclusion in PubMed, CAS, Scopus and Google Scholar

- Research which is freely available for redistribution

Submit your manuscript at www.biomedcentral.com/submit
C) Biomed Central 